\title{
NEEDS ASSESSMENT OF GUIDANCE SERVICES IN SCHOOLS AS A METHOD FOR ACHIEVING QUALITY EDUCATION IN NIGERIA: AN EXPLORATION STUDY
}

\author{
ESERE Mary Ogechim PhD \\ Department of Counsellor Education \\ University of Ilorin, Ilorin \\ email: maryogechim@yahoo.com \\ OMOTOSHO, A. Joshua PhD \\ Department of Counsellor Education \\ University of Ilorin, Ilorin, \\ email: joshtoshpa@yahoo.com \\ and \\ EWENIYI, G. B. PhD \\ Department o Educational Foundations \& Counselling \\ Olabisi Onabanjo University \\ Ago-Iwoye
}

\begin{abstract}
The researchers conducted this study in order to establish a case for the use of needs assessment of guidance services as a means of achieving quality education in Nigeria. They contacted 84 professional counsellors in Ilorin, a typical Nigerian metropolis, in order to gather data on their perception of the importance of certain guidance services in secondary schools. They also determined the actual level of services rendered in schools. The instrument used for collecting the necessary data was titled "Guidance Service Rendered to Students Questionnaire" GUSRESQ. The findings indicated a need to use needs assessment of guidance services for obtaining higher levels in the quality of education. The findings also indicated that practicing counsellors perceive counselling service and information service as the most important.
\end{abstract}


Needs Assessment of Guidance Services in Schools as A Method For Achieving Quality Education in Nigeria:

An Exploration Study

Esere M.0., 0motosho J.A, \& Eweniyi G.B.

Key Words: Academic programme evaluation; counselling; educational standards; guidance services; needs assessment.

\section{Introduction}

A need can be defined simply as the difference between the real and the ideal. It is a discrepancy between "what is" and "what should be", or between "what exists" and "what ought to be". Using this notion, Kaufman and English (1979) described an educational need as "the measurable distance between 'where we are now' and 'where we should be'. According to Omotosho (1985), such discrepancy really becomes a need if and when it is viewed as a critical problem requiring solution.

Needs assessment has been defined by Bell (1974) as the process of identifying and analyzing needs, and placing priorities among them for the purpose of decision making. It is an attempt, according to Bell, to answer the following questions:

1. What should be the priority goals of the institution?

2. What are the performance deficiencies of the institution?

3. What is the institution doing that it should not do?

4. What is the institution doing that it should be doing?

5. What desired competencies in the students should receive more emphasis?

6. What deficiencies should be given more attention?

7. Taking into account the fact that the resources that are available are limited, what programmes should be given more emphasis and what should be given less?

(pp.38-39).

Ebie and Mckeachie (1985) posited that the standard of undergraduate education can be raised through the use of needs assessment study data. Stoops, Rafferty, and Johnson (1975) have asserted that needs assessments are common in the area of curriculum development and that they have also been successfully applied to other areas such as educational finance, administration, personnel evaluation, transportation services, and so forth. Furthermore, according to these authors, an array of need assessment approaches is now in use through questionnaire, interviews, and surveys. Also parents and alumni could be requested to identify the needs of a school district through such a study.

Many of the commonly used approaches to needs assessment could be grouped under what Kaufman (1972) termed "discrepancy analysis". 
He described it as "the process of determining and documenting a measurable difference between two states of affairs" saying that there is a great deal of variation in using this approach. However, Brittingham and Netusil (2008) recognized the following activities as constituting the basic procedure:

1. Listing the full range of possible goals (or objectives);

2. Determining the relative importance of the goals (or objectives);

3. Assessing the degree to which the important goals (or objectives) are being achieved by the programme (i.e. identifying discrepancies between desired and actual performance); and

4. Determining which of the discrepancies between the present and desired performance are the most important to correct. (p.184)

A publication by Witkin and Altshuld (1995) has spelt a practical guide for planning and conducting needs assessment studies. The activities they discussed are vitally important if one desires to achieve good success in a needs assessment study of any educational programme.

The common concern in educational circles in Nigeria today is about "falling standards". The dissatisfaction with school curricula is freely expressed in the press, on the television, radio, public platforms by parents and by the man in the street. That is why it behoves us in academia to do all we can to ensure that we keep the standards of education from falling further down. We must determine to make our education have quality that is sufficiently high enough to compete with the qualities found in other parts of the world. Counsellors particularly, because of the importance and uniqueness of our professional role in the scheme of things, must ensure that the guidance services rendered by counsellors in the schools help to facilitate efforts at giving quality education to all Nigerians. Hyman (1983) has rightly admonished us all on the need for quality education with his quotation of Alexander Pope's piquant verse from his 'An essay on criticism', thus:

A little learning is a dangerous thing; Drink deep, or taste not the Pierian spring; There shallow draughts intoxicate the brain, And drinking largely sobers us again. (p.249) 
Needs Assessment of Guidance Services in Schools as A Method For Achieving Quality Education in Nigeria:

An Exploration Study

Esere M.0., 0motosho J.A, \& Eweniyi G.B.

\section{Purpose}

From all that has been said above, the reader will agree that the following merits (or positive points), among others, can accrue to those who use needs assessment approaches for evaluating educational programmes of any type:

1. It facilitates programme or service improvement and/or modification because of its in-built mechanism for easily detecting areas of the programme needing more or less attention/emphasis (Bell, 1974);

2. It is cost-effective, easy and cheap to conduct as compared to other approaches to evaluating an educational programme (Omotosho, 1985 and Bell, 1974);

3. It helps to answer pertinent questions that are crucial to finding answers to the issue of quality education (Bell, 1974); and

4. It helps in listing and setting educational objectives and goals, a process that enhances quality in education (Brittingham and Netusil, 2008).

It is on account of the foregoing that these researchers submit the proposal that needs assessment should be used in the evaluation of guidance services of secondary schools in Nigeria in particular and in other developing countries in general. This would help to facilitate the achievement of higher quality education in these countries. In order to demonstrate how this can be done the researchers undertook the needs assessment study reported below as an exploratory study.

\section{Method}

\section{Sample and Sampling Procedure}

The target population for this study was all school counsellors employed to practice their counselling services in secondary schools in Ilorin metropolis. By virtue of the small size of the total number of such person (less than 100 persons) functioning as counsellors in secondary schools in Ilorin metropolis, it was decided from the onset that the sample would be a captive audience. In other words, counsellors in all the 50 odd secondary schools in Ilorin metropolis were earmarked to form the sample. Hence, in the week chosen for distributing and collecting the questionnaire, the research assistants (10 master's degree level students 
taking a course titled "Guidance and Counselling in Nigerian Educational System", EGC 654, taught by one of the researchers) shared the schools among themselves for visitation, each of them being assigned to visit five schools.

Prior to the visit to schools, the research assistants were given adequate and relevant instructions in class regarding how to distribute and retrieve the questionnaire forms. These included how they were to obtain permission from school authorities before embarking on their assignment, how they were to locate the prospective respondents, and how they were to guide each respondent in completing the questionnaire form accurately. On the whole, 84 counsellors were reached and they therefore formed the sample for the study.

\section{Instrumentation}

The instrument for data collection was titled "Guidance Services Rendered to Students Questionnaire" (GUSRESQ). It was developed for this purpose by the researchers after a perusal of relevant literature on the topic. The validity of GUSRESQ was established, after its construction, by requesting two other lecturers with specialization in Guidance and Counselling and another with specialization in Measurement and Evaluation to vet it for content validity.

After ascertaining its validity it was then subjected to the test-retest method to establish its reliability coefficient. Ten counsellors were first served with the questionnaire. After an interval of four weeks the exercise was repeated for the same group of counsellors. By means of the Pearson Product Moment Correlation Coefficient method the coefficient of reliability ( $\mathrm{r}$ ) was computed. A Pearson $\mathrm{r}$ of magnitude 0.89 , significant at the 0.05 level of significance was obtained. The GUSRESQ contains a list of what Adana (2004) called "the common guidance services in a good school guidance programme" (p.85). These were listed alphabetically down the page of the questionnaire form thus: Appraisal Service; Counselling Service; Follow-up Service; Information Service; Orientation Service; and Placement Service.

Respondents were instructed to do two things with the list. Firstly, they were required to rank-order, on the left hand-side spaces the services in the order they perceived them to be important as guidance services needed in the schools. Hence, they were to write on the left of the services $1^{\text {st }}$ against the service they perceived as the most important; $2^{\text {nd }}$ against the service they perceived as the next most important... and $6^{\text {th }}$ against the service they perceived as the least important (Table 1). 
Needs Assessment of Guidance Services in Schools as A Method For Achieving Quality Education in Nigeria:

An Exploration Study

Esere M.0., 0motosho J.A, \& Eweniyi G.B.

Secondly, in the right hand side, they were to tick $(\sqrt{ })$ only the guidance service(s) that they actually rendered to students. In other words, they were to tick $(\sqrt{ })$ the brackets of all guidance services they normally rendered to students, and to leave blank the brackets of the guidance services they did not normally render to students.

\section{Data Analysis}

The data obtained as indicated were collated. On the perceived side (left hand side) where ranking was required, the weights assigned to the different ranks were as follows: 6 units for 1st position; 5 units for 2nd position; 4 units for 3rd position; 3 units for 4th position; 2 units for 5th position; and 1 unit for 6th position. For data on the right hand side of the alphabetical list of services, normal frequency counts were used to sum up the number of times any of the guidance services was ticked $(\downarrow)$.

For this study, the weight of each of the counselling services was obtained by the number of times it was chosen as 1st by respondents was multiplied by 6 (the weight assigned to 1st position). Thus a sub-sum corresponding to 1st position was obtained. Next, the number of times that service was chosen as 2 nd by respondents was multiplied by 5 , (the weight assigned to 2 nd position). Thus a second sub-sum corresponding to 2 nd position was obtained. This process was repeated for $3 \mathrm{rd}$, 4 th, 5 th and 6th positions for that service, thus giving six sub-sums which when summed together gave the grand sum weight found in the weight column of Table 1.

\section{Results}

The results of these analyses are displayed in Table 1.

Table 1: Showing Perceived Importance and Actual Rendering of Guidance Services

\begin{tabular}{|l|c|c|c|c|}
\hline \multicolumn{1}{|c|}{ Guidance Service } & \multicolumn{2}{c|}{$\begin{array}{c}\text { Perceived } \\
\text { Importance of the } \\
\text { Service }\end{array}$} & \multicolumn{2}{c|}{$\begin{array}{c}\text { Actual Rendering of } \\
\text { the Service }\end{array}$} \\
\hline & Weight & Rank & Frequency & Rank \\
\hline Appraisal Service & 235 & $5^{\text {th }}$ & 37 & $5^{\text {th }}$ \\
\hline Counselling Service & 391 & $1^{\text {st }}$ & 76 & $1^{\text {st }}$ \\
\hline Follow-up Service & 196 & $6^{\text {th }}$ & 33 & $6^{\text {th }}$ \\
\hline Information Service & 337 & $2^{\text {nd }}$ & 76 & $1^{\text {st }}$ \\
\hline Orientation Service & 304 & $3^{\text {rd }}$ & 58 & $3^{\text {rd }}$ \\
\hline Placement Service & 290 & $4^{\text {th }}$ & 56 & $4^{\text {th }}$ \\
\hline
\end{tabular}


Table 1 was used to depict the results obtained from analysis of the data. In the "Perceived Importance" section it can be seen that Counselling Service was perceived/seen by counsellors in Ilorin metropolis to be the most important guidance service in the secondary school system (391 units). This was followed by Information Service with 337 units. The guidance service perceived as being the least important was Follow-up Service (Table 1).

On the other hand, the guidance services, in terms of rendering them in actual practice, that were most frequently ticked by respondents were Counselling Service and Information Service both of which tied for $1^{\text {st }}$ place. The least rendered guidance service by counsellors in Ilorin metropolis was Follow-up Service (Table 1).

\section{Discussion}

The results of this study have shown that counsellors in Ilorin metropolis perceived Counselling Service as the most important service of the school's guidance programme. This is a corroboration of Idowu's (2004) position. Idowu had posited that counselling is "the heart or core of guidance, the hub of the guidance wheel or the pivotal specific service around which the wheel of guidance revolves" (p.16). A similar submission had been made by Shertzer and Stone (1981) earlier, and these imply that Counselling Service supersedes all others as the most important guidance service in the school's guidance programme. It was not surprising, therefore, that the same Counselling Service and with Information Service tied for $1^{\text {st }}$ place as the service actually rendered by counsellors in the school system. In each case, 76 of the 84 counsellors ( $90.5 \%$ or approximately 9 out of every 10 counsellors) render this service to students!

In the perception of the counsellors, Information Service was perceived as the second most important service in the school system. This is also understandable considering the fact that information is very vital for making wise decision and choices in life, particularly for youths, preparatory to entering the world of work. Prediger, Roth and Noeth (1975) and Zunker (2006) have noted rightly that knowledge of the world of work and the career planning process is a major component of career development and that such knowledge is acquired through the Information Service component of the school's guidance programme.

For both Perceive Importance and Actual Rendering, Follow-up Services are very unpopular in the Nigerian educational system. In an 
earlier study, Omotosho (1995) had found that as large a proportion as $62.8 \%$ (about 5 of every 8 ) lecturers in three tertiary institutions in Ilorin had never been followed up throughout their school and working years! Also, 38.0\% had no knowledge of what follow-up studies of former students of an educational institution are at all!

\section{Conclusion}

On the basis of the findings above, the following conclusions are reached:

- Counselling Service, as the hub of the guidance wheel, as well as Information Service are very vital services in the school's guidance programme in Ilorin.

- Counselling Service, and Information Service are the two services rendered most by school counsellors.

- Follow-up Service is perceived both as the least important and as the least rendered.

\section{Recommendations}

Emanating from the conclusions reached above, Counselling Service and Information Service should receive priority attention by lecturers in counsellor training programmes since these two are the services they use most among students. A note of caution, however, is in order here: Another needs assessment study would have to be carried out among students themselves for the guidance services of the school before confirming the above recommendation.

Needs assessment studies should be carried out in several areas/units of the guidance programme in order to discover desired competencies which students in counsellor training find most useful in the field. It is also critical, according to Leigh, Watkins, Platt and Kaufman (2000) to ensure that the right or most appropriate model is selected for conducting such needs assessment studies.

If the recommendations mentioned above are considered, the guidance programmes of our schools will be able to meet the needs of students, the ultimate consumers of our efforts. In this way, they will be able to brace up to the demands which their academic pursuits make on them and this will contribute to the achievement of quality education in Nigeria and, for that matter, in other developing countries which attempt it.

Since needs assessment studies have been conducted with relatively high measures of success in various fields of specialization (e.g. for 
faculty development in community colleges: Murray, 1999; for career paths and roles of lecturers: Fulgate and Amey, 2000; for applied arts and technology colleges in Ontario: Jones and Geis, 1995; and for physical therapy education: Goldstein and Gandy, 2001; etc.), time is now ripe for the Counselling Association of Nigeria (CASSON) to blaze the trail by encouraging its state chapters and individuals to embark on such studies because of their potential for improving the quality of education as highlighted in this paper.

\section{References}

Adana, B. S. (2004). The school guidance programme. In A.I. Idowu (Ed). Guidance and Counselling in education (2nd ed.), pp. 50-67. Ilorin: Indemac.

Bell, T.H. (1974). A performance accountability system for school administration. West Nyack: Parker.

Brittingham, B.E. \& Netusil, A.J. (2008). The reliability of goal ratings in a needs assessment procedure. Retrieved February 1, 2008 from http://www.eric.ed.gov/

ERICWebPortal/custom/portlets/recordDetails/detail/mini.jsp?

Ebie, K.E. \& McKeachie, W.J. (1985). Improving undergraduate education through faculty development. San Francisco, C.A.: Jossey-Bass Inc. Publishers.

Fugate, A.L. \& Amey, M.J. (2000). Career stages of community college faculty: A qualitative analysis of their career paths, roles and development. Community College Review, 28, 1-22.

Goldstein, M.; \& Gandy, J. (2001). Applicants to professional therapist programmes in 2000. Journal of Physical Therapy Education, 15(3), 919.

Hyman, R. (1983). A dictionary of famous quotations. London: Pan Books.

Idowu, A. I. (2004). Guidance and counselling: An overview. In A. I. Idowu (Ed). Guidance and counselling in education. Ilorin: Indemac.

Jones, G. A.; \& Geis, G. L. (1995). Faculty development structures and activities in Ontario's colleges of applied arts and technology. Canadian Journal of Higher Education, 25, 41-61.

Kaufman, R. A. \& English, F.W. (1979). Needs assessment: Concept and application. Eaglewood Cliffs, N.J.: Educational Technology Publications.

Kaufman, R. A. (1972). Education system planning. Eaglewood Cliffs, N.J. Prentice Hall. 
Leigh, D.; Watkins, R.; Platt, W. A. \& Kaufman, R. (2000). Alternative models of needs assessment: Selecting the right one for your organization. Human Resources Development Quarterly, 11,87-93.

Murray, J.P. (1999). Faculty development in a national sample of community colleges. Community College Review, 27, 47-64.

Omotosho, J. A. (1985). A needs assessment follow-up study of the former students of the guidance, counselling and student personnel of Ohio University who graduated between August 1977 and June 1982. Dissertation Abstract International, 45(08), 2399A-2400A.

Omotosho, J. A. (1995). Follow-up studies of former students as an effective measure of the effect of schooling. In B. Ipaye (Ed). Research on schooling in Nigeria: Introductory readings. Lagos: Chayoobi Printers \& Publishers.

Prediger, D. J.; Roth, J.D.; \& Noeth, R.J. (1975). Career development of youth: A nationwide study. Personnel and Guidance Journal, 54, 1219.

Shertzer, B. \& Stone, S.C. (1981). Fundamentals of guidance (4th ed). Boston: Haughton Mifflin Co.

Stoops, E.; Rafferty, M. \& Johnson, R. E. (1975). Handbook of educational administration: A guide to the practitioner. Boston: Allyn and Bacon.,

Witkin, B. R. \& Altshuld, J. W. (1995). Planning and conducting needs assessment: A practical guide. Thousand Oaks, C.A.: Sage.

Zunker, V. G. (2006). Career counselling: A holistic approach. Belmont, C.A.: Thomson Brooks/Cole. 